Tersedia online di: http://ejournal-balitbang.kkp.go.id/index.php/jra

\title{
SENSITIVITAS DETEKSI PENYAKIT VIBRIOSIS PADA UDANG PENAEID DENGAN PENANDA MOLEKULER SPESIFIK HAEMOLYSIN (IAVh)
}

\author{
Ince Ayu Khairana Kadriah\#, Koko Kurniawan, Endang Susianingsih, dan Muharijadi Atmomarsono
}

Balai Penelitian dan Pengembangan Budidaya Air Payau

\begin{abstract}
ABSTRAK
Penyakit vibriosis pada budidaya udang dapat menyebabkan penurunan produksi yang cukup besar. Metode deteksi cepat akan sangat membantu dalam penanganan dan pencegahan awal untuk mengurangi kematian udang. Upaya untuk deteksi cepat adalah dengan menggunakan penanda molekular yang spesifik. Tujuan dari penelitian ini adalah untuk mengukur sensitivitas metode deteksi vibriosis pada udang penaeid (windu dan vaname) menggunakan penanda molekuler spesifik haemolysin (IAVh). Pengujian dilakukan untuk sampel udang yang diinfeksi buatan melalui injeksi maupun pada sampel yang dikoleksi dari tambak udang. Sampel organ udang hasil infeksi buatan ditanam pada media TCBSA untuk melihat koloni bakteri yang tumbuh. Selanjutnya koloni bakteri tersebut diuji secara biokimia dan molekuler. Deteksi vibriosis untuk sampel dari tambak budidaya hanya dilakukan secara molekuler menggunakan primer spesifik IAVh. Lokasi pengambilan sampel udang dari Provinsi Sulawesi Selatan (Kabupaten Takalar, Kabupaten Maros, Kabupaten Pangkep, Kabupaten Bulukumba, Kabupaten Barru, dan Kabupaten Pinrang), Provinsi Lampung (Desa Bakauheni dan Kalianda), Provinsi Jawa Timur (Kabupaten Situbondo) dan Provinsi Jawa Barat (Kabupaten Karawang). Hasil uji biokimia untuk sampel dengan infeksi buatan dapat menentukan spesies bakteri, namun waktu yang diperlukan relatif lama. Hasil uji menggunakan penanda molekuler haemolysin IAVh dapat secara spesifik mendeteksi vibrio patogen pada kepadatan bakteri $10^{2}-10^{3} \mathrm{CFU} / \mathrm{mL}$ dari organ udang, baik pada sampel hasil infeksi buatan maupun pada sampel dari tambak.
\end{abstract}

KATA KUNCl: deteksi cepat; haemolysin; uji biokimiawi udang penaeid; vibriosis

ABSTRACT: Sensitivity of the specific molecular marker of haemolysin (IAVh) for vibriosis detection on black tiger shrimp. By: Ince Ayu Khairana Kadriah, Koko Kurniawan, Endang Susianingsih, and Muharijadi Atmomarsono

Vibriosis disease may causea significant production losses in shrimp culture. The rapid detection method will be be very effective as earlier preventive measures to avoid mass mortality of shrimp. Effort for the rapid detection was done by specific molecular marker. The aim of this research was to evaluate the sensitivity of the specific molecular marker of haemolysin (IAVh) for vibriosis detection. Vibriosis detection was carried-out for both naturally infected shrimp and artificially infected through injection. Several organs of artificially-infected shrimp grown on TCBS media to find identify colonies of bacteria. After this, colonies of bacteria weretested biochemically and molecularly. Penaeid shrimp samples were collected from the shrimp brackishwater ponds in the South Sulawesi Province (Takalar Regency, Maros Regency, Pangkep Regency, Bulukumba Regency, Barru Regency, and Pinrang Regency). Lampung Province (Bakauheni and Kalianda District), East Java Province (Situbondo Regency) and West Java Province (Karawang Regency). The results of biochemical assay for artificially-infected shrimp could determine the species of vibrioses, but it took a relatively long time. The further results showed that specific molecular marker of haemolysin (IAVh) could detect Vibriosis directly from the shrimp organs in at density of $10^{2}-10^{3} \mathrm{CFU} / \mathrm{mL}$ on both natural and artificial infected vibrioses shrimp.

KEYWORDS: biochemical test; early detection; haemolysin; penaeid shrimp; vibriosis

\section{PENDAHULUAN}

Akuakultur dipandang sebagai salah satu sumber pangan yang cukup penting bagi populasi manusia di

\footnotetext{
\# Korespondensi: Balai Penelitian dan Pengembangan Budidaya Air Payau. Jl. Makmur Dg. Sitakka No. 129, Maros 90512,

Sulawesi Selatan, Indonesia. Tel. + (0411) 371544

E-mail: inceayu@gmail.com
}

dunia, dan telah berkembang pesat karena metode kultur intensif (Hai, 2015). Seperti halnya usaha pertanian, industri akuakultur juga mengalami hambatan yang cukup serius akibat adanya serangan penyakit. Vibrio harveyi adalah patogen penyebab penyakit kunang-kunang yang banyak menyerang komoditas budidaya yang menyebabkan kerugian besar dalam industri akuakultur (Austin \& Zhang, 2006). 
Selama ini identifikasi dan deteksi penyakit kunang-kunang udang dilakukan dengan pengamatan berdasarkan gejala klinis yang terlihat di tambak dan dilanjutkan dengan pengujian di laboratorium. Kejadian penyakit tersebut selalu ditandai dengan terjadinya fenomena udang dan air bercahaya (bioluminescence). Gejala lainnya adalah udang terlihat lemah dalam pergerakannya dan mengalami nekrosis (Karunasagar, 1994). Leano (1998) menyatakan bahwa pada saat udang telah mengalami gejala-gejala klinis seperti yang disebutkan di atas, maka konsentrasi bakteri Vibrio pada hepatopankreas sudah mencapai kepadatan $10^{5}$ $10^{6} \mathrm{CFU} / \mathrm{mL}$. Kepadatan di atas atau sama dengan $10^{5}$ CFU/mL menurut Leano (1998), adalah kepadatan yang cukup untuk menjadikan bakteri Vibrio bersifat patogen di alam. Hal inilah yang menyebabkan sulitnya untuk melakukan upaya pencegahan penyakit jika berdasarkan munculnya gejala klinis seperti adanya pendaran cahaya di air tambak karena kepadatan bakteri patogen sudah tinggi.

Metode biokimia yang digunakan untuk mendeteksi memerlukan waktu beberapa hari untuk dapat memperoleh hasil. Di samping hasil metode agar sebar seringkali tidak dapat mendeteksi keberadaan bakteri patogen di antara bakteri non-patogen. Hal ini menjadi kendala dalam mengendalikan wabah epidemi. Pesatnya perkembangan teknik biologi molekuler memberikan peluang baru yang signifikan untuk penelitian diagnosis penyakit ikan dan udang. Beberapa teknik molekuler untuk identifikasi seperti Random Amplified Polymorhic DNA (RAPD) dan analisis sekuensing gen 16s-rRNA (Dorsch et al., 1992) tetap belum mampu secara spesifik membedakan antra Vibrio patogen dan non-patogen. Menggunakan asam nukleat sebagai target, dan metode baru yang menganalisis polimorfisme dalam asam nukleat, dapat meningkatkan spesifisitas, sensitivitas, dan kecepatan diagnosis, serta cara baru untuk memeriksa hubungan antara genotipe dan fenotipe dari berbagai patogen. Kemajuan dalam teknik PCR sangat membantu studi epidemiologi, serta identifikasi penyebab wabah penyakit atau deteksi patogen (Cunningham, 2002).

Gen spesifik yang dimiliki oleh bakteri Vibrio berpendar dapat digunakan sebagai penanda molekular dalam diagnosis cepat penyakit ini. Gen haemolysin diketahui merupakan salah satu gen spesifik yang dimiliki bakteri patogen termasuk bakteri Vibrio. Gen haemolysin adalah gen yang bertanggung jawab pada penghancuran membran sel darah atau proses hemolisis (Conejero \& Hedreyda, 2004). Selain gen haemolysin, pada beberapa pustaka rujukan juga disebutkan gen toxR (Pang et al., 2006). Pada penelitian sebelumnya telah berhasil didesain penanda spesifik molekuler untuk Vibrio patogen pada udang penaeid (udang windu dan vaname). Penanda spesifik ini didesain menggunakan metode PCR dengan gen haemolysin sebagai gen target (Kadriah et al., 2013a). Spesifisitas dan sensitivitas dari penanda molekuler merupakan dua hal yang sangat penting untuk diuji. Hasil pengujian spesifisitas dari penanda molekuler yang didesain menunjukkan bahwa hanya DNA dari bakteri Vibrio patogen yang berasal dari udang penaeid yang teramplifikasi, sedangkan DNA dari bakteri Vibrio non-patogen, serta bakteri patogen non-Vibrio tidak dapat teramplifikasi (Kadriah et al., 2013b). Hasil uji sensitivitas menunjukkan konsentrasi terendah yang dapat dideteksi adalah $10^{2}$ hingga $10^{3} \mathrm{CFU} / \mathrm{mL}$. Pengujian sensitivitas dan spesifisitas ini dilakukan pada skala laboratorium.

Tujuan penelitian ini adalah untuk mengetahui sensitivitas penanda molekuler spesifik IAVh (Kadriah et al., 2013a) dalam mendeteksi Vibrio berpendar patogenik yang menjadi agen vibriosis baik pada sampel hasil infeksi buatan maupun pada sampel yang dikoleksi dari tambak udang. Hasil dari penelitian ini diharapkan dapat memperbaiki metode deteksi Vibrio patogen dengan lebih cepat pada udang penaeid (udang windu dan vaname).

\section{BAHAN DAN METODE}

\section{Infeksi Buatan dengan Vibrio Berpendar Patogen}

Udang yang digunakan untuk uji ini adalah udang windu ukuran tokolan berumur satu bulan di tambak. Udang uji terlebih dahulu telah didepurasi selama satu minggu dalam bak terkontrol untuk meminimalisasi adanya kontaminasi dari bakteri patogen lainnya. Selama seminggu masa karantina, sistem yang digunakan adalah sistem air mengalir. Sebelumnya telah dilakukan proses sterilisasi air media dengan menggunakan kaporit $\mathrm{Ca}(\mathrm{OCl})_{2} 150 \mathrm{mg} / \mathrm{L}$ selama 24 jam.

Sebelum melakukan uji deteksi Vibriosis, terlebih dahulu dilakukan infeksi buatan menggunakan Vibrio harveyi berpendar patogen dengan metode penyuntikan. Bakteri V. harveyi patogen yang akan diinfeksikan terlebih dahulu dikultur di media nutrient broth (NB) selama 24 jam. Setelah 24 jam, biakan bakteri dipindahkan ke media NB baru dan dikultur selama empat jam sebelum diinfeksikan ke hewan uji. Konsentrasi bakteri setelah re-kultur empat jam adalah $10^{8} \mathrm{CFU} / \mathrm{mL}$ (Kadriah, 2012). Konsentrasi bakteri yang akan diinfeksikan ke udang diatur menggunakan metode pengenceran dengan larutan saline solution (SS). 
Penyuntikan bakteri V. harveyi dilakukan pada ruas terakhir kaki jalan dengan volume $100 \mu \mathrm{L}$ biakan bakteri dengan tiga konsentrasi yaitu $10^{2}, 10^{4}$, dan $10^{6} \mathrm{CFU} / \mathrm{mL}$. Jumlah udang yang diinfeksi untuk setiap perlakuan adalah lima ekor. Pengambilan udang dilakukan setiap ada udang yang mengalami gejala sakit (moribund) sebelum mati. Organ udang yang diambil untuk keperluan deteksi vibriosis adalah kaki jalan, kaki renang, insang, dan ekor.

Wadah penelitian yang digunakan adalah akuarium kapasitas $10 \mathrm{~L}$ sebanyak 12 buah. Setiap wadah diisi air laut dengan salinitas 28 ppt yang telah disterilkan dengan kaporit $150 \mathrm{mg} / \mathrm{L}$ selama satu malam dan kemudian dinetralisir dengan natrium thiosulfat $75 \mathrm{mg} / \mathrm{L}$. Volume air laut yang diisikan ke dalam wadah sebanyak $5 \mathrm{~L}$.

\section{Koleksi Sampel Udang}

Sampel udang dikoleksi dari tambak budidaya di Provinsi Sulawesi Selatan (Kabupaten Takalar: enam sampel udang vaname, Kabupaten Maros: 10 sampel udang windu, Kabupaten Pangkep: empat sampel udang windu, Kabupaten Bulukumba: empat sampel udang windu, Kabupaten Barru: tiga sampel udang windu, dan Kabupaten Pinrang: tujuh sampel udang windu dan udang vaname. Provinsi Lampung (Desa Bakauheni dan Kalianda: enam sampel udang vaname), Provinsi Jawa Timur (Kabupaten Situbondo: sembilan sampel udang windu), dan Provinsi Jawa Barat (Kabupaten Karawang: empat sampel udang windu). Organ udang yang dikoleksi adalah kaki renang, kaki jalan, tutup insang, insang, hepatopankreas, dan ekor. Sampel diawetkan di dalam larutan TNES sebelum dibawa ke laboratorium.

\section{Deteksi Vibriosis Secara Biokimiawi}

Deteksi Vibriosis secara konvensional dengan metode biokimia ini hanya dilakukan pada sampel udang hasil infeksi buatan. Deteksi vibriosis dengan metode biokimia menggunakan 25 macam uji. Pada tahapan ini terlebih dahulu dilakukan penumbuhan bakteri pada media spesifik TCBSA dari organ udang yang telah diinfeksi secara buatan dengan metode injeksi. Organ udang yang dikoleksi adalah ekor dan kaki renang. Selain dari organ udang sakit isolasi bakteri juga dilakukan dari haemolim. Haemolim dari udang sakit diambil dengan syringe $1 \mathrm{~mL}$ yang dilengkapi jarum 25 Gauge dan kemudian diteteskan di atas media TCBSA, sedangkan organ udang sakit ditempelkan langsung ke atas media TCBSA. Pengamatan morfologi koloni bakteri yang tumbuh di TCBSA dilakukan setelah 24 jam. Bakteri berpendar dapat diamati setelah 18-20 jam setelah dikultur. Koloni bakteri yang tumbuh selanjutnya diseleksi berdasarkan bentuk koloni, warna, dan pendarannya untuk dilakukan uji lanjutan secara biokimia. Dari hasil seleksi secara morfologi diperoleh lima isolat yang akan diuji sifat sifat fisiologisnya secara biokimia.

Setelah koloni bakteri tumbuh pada media TCBSA, kemudian dilakukan uji biokimia terhadap isolat terpilih dengan 25 macam uji untuk mengidentifikasi jenis bakteri yang tumbuh. Uji biokimia dilakukan berdasarkan metode yang dilakukan oleh Austin (1991); Austin \& Austin (1993); Alsina \& Blanch (1994); Baumann et al. (1994); Brock et al. (1994); Muir (1996a). Untuk menentukan spesies dari bakteri Vibrio berpendar, data hasil uji biokimia yang diperoleh diolah dengan menggunakan perangkat lunak Fortran Computer Program (Muir, 1996b). Analisis uji biokimia dilakukan 48 jam setelah pengujian, kecuali untuk uji asam amino xanthine yang membutuhkan waktu lima hari untuk mendapatkan hasil.

\section{Deteksi Vibriosis Secara Molekuler}

Deteksi vibriosis secara molekuler dilakukan pada sampel udang hasil uji infeksi buatan skala laboratorium dan sampel udang yang dikoleksi dari beberapa tambak pembesaran di daerah-daerah sentra perudangan nasional. Uji deteksi vibriosis secara molekuler menggunakan metode PCR dengan primer spesifik IAVh (Kadriah, 2012). Proses deteksi dilakukan di Laboratorium Kesehatan Ikan dan Lingkungan Balai Penelitian dan Pengembangan Budidaya Air Payau.

Sebelum dilakukan deteksi secara molekuler dengan amplifikasi DNA menggunakan PCR, terlebih dahulu dilakukan ekstraksi genom DNA dari organ udang yang dikoleksi. Ekstraksi genom DNA menggunakan metode DTAB-CTAB (Dodecyl Trimethyl Ammonium Bromide/Cetyl Trimethyl Ammonium Bromide) (Mamiatis et al., 1982). Genom DNA udang yang diperoleh selanjutnya diamplifikasi dengan mesin PCR dan menggunakan primer spesifik IAVh sebagai pendeteksi keberadaan bakteri patogen pada sampel udang. Proses PCR dilakukan menggunakan metode Kadriah (2012). Program PCR untuk primer haemolysin diatur sebanyak 25 siklus pada suhu denaturasi $94^{\circ} \mathrm{C}$ selama satu menit, annealing $63^{\circ} \mathrm{C}$ selama satu menit 30 detik, dan elongasi $68^{\circ} \mathrm{C}$ selama satu menit 30 detik, serta tahap ekstra elongasi $72^{\circ} \mathrm{C}$ selama 10 menit. Proses PCR ini dilakukan dua kali (re-PCR) untuk meningkatkan sensitivitas hasil deteksi.

Hasil PCR kemudian diseparasi pada gel agarosa $2 \%$ untuk diobservasi dan didokumentasikan. Hasil visualisasi dari gel elektroforesis bila terlihat pita (band) pada panjang basa 151 bp untuk gen haemolysin menunjukkan adanya infeksi bakteri Vibrio berpendar patogenik pada sampel udang yang dikoleksi. 


\section{HASIL DAN BAHASAN}

Selama ini deteksi Vibrio berpendar masih menggunakan teknik mikrobiologi standar. Namun, metode ini tidak dapat mendeteksi patogen pada tahap awal infeksi atau mungkin memiliki sensitivitas deteksi.yang lebih rendah (Christopher et al., 2011). Dengan demikian, metode lain terutama metode deteksi berbasis molekul seperti polymerase chain reaction (PCR) telah dikembangkan untuk memberikan penentuan cepat dan akurat dari patogen pada tahap awal infeksi. Metode deteksi menggunakan gen spesifik IAVh diharapkan dapat lebih spesifik dan sensitif mendeteksi keberadaan bakteri patogen pada media dan udang yang dibudidayakan sebelum munculnya gejala klinis di tambak.

\section{Hasil Deteksi Vibriosis untuk Sampel Infeksi Buatan}

Hasil deteksi vibriosis dengan metode konvensional menggunakan media agar TCBS dan uji biokimia dapat dilihat pada Gambar 1. Hasil penanaman bakteri dari organ udang sakit menunjukkan bahwa bakteri yang tumbuh pada media selektif TCBSA hampir semuanya berwarna kuning. Demikian pula bakteri yang tumbuh dari haemolim tidak ditemukan adanya koloni bakteri yang berwarna hijau. Pengamatan bakteri berpendar setelah 20 jam menunjukkan tidak ada koloni bakteri yang berpendar baik yang berasal dari organ maupun haemolim udang sakit. Dari hasil ini dapat disimpulkan bahwa bakteri patogen yang diinfeksikan tidak berhasil dideteksi kembali dengan metode konvensional Koloni bakteri yang dipilih untuk uji biokimia hanya ada lima koloni yang memiliki perbedaan morfologi dari semua konsentrasi bakteri yang diinfeksikan secara buatan.

Hasil uji biokimia mengindikasikan bahwa spesies bakteri yang tumbuh pada media TCBSA adalah bakteri V. mimicus, V. harveyi, V. mimicus/harveyi, dan V. campbelli (Tabel 1). Berdasarkan hasil uji biokimia dapat diterangkan bahwa metode deteksi konvensional hanya dapat mengidentifikasi spesies bakteri setelah lima hari waktu pengamatan. Waktu yang cukup lama bila dibandingkan metode deteksi molekuler yang hanya membutuhkan waktu 1-2 hari. Ketidakmampuan metode biokimia untuk mendeteksi secara spesifik keberadaan bakteri Vibrio patogen pada sampel menjadi acuan untuk selanjutnya melakukan deteksi vibriosis pada sampel dari tambak hanya menggunakan metode deteksi molekuler.

Hasil deteksi vibriosis secara molekuler pada udang yang diinfeksi buatan dapat dilihat pada Gambar 2. Deteksi ini menggunakan metode molekuler dengan primer speisifk IAVh. Pada Gambar 2, terlihat jelas pita-pita DNA hasil amplifikasi PCR dan diseparasi dengan elektroforesis pada panjang basa 151 bp. Hasil ini menunjukkan bahwa deteksi Vibrio patogen secara molekuler dengan penanda spesifik hemolisin lebih sensitif dibandingkan metode biokimia. Keberadaan bakteri patogen dapat dideteksi dengan spesifik dan sensitif secara langsung terhadap gen hemolisin pada organ udang sakit. Keberadaan gen hemolisin menunjukkan adanya infeksi bakteri Vibrio patogen pada sampel yang diuji.

Pada penelitian yang dilakukan oleh Liu et al. (1996), isolat bakteri Vibrio dari udang windu (P. monodon) dan udang kuruma (P. japonicus) menunjukkan aktivitas

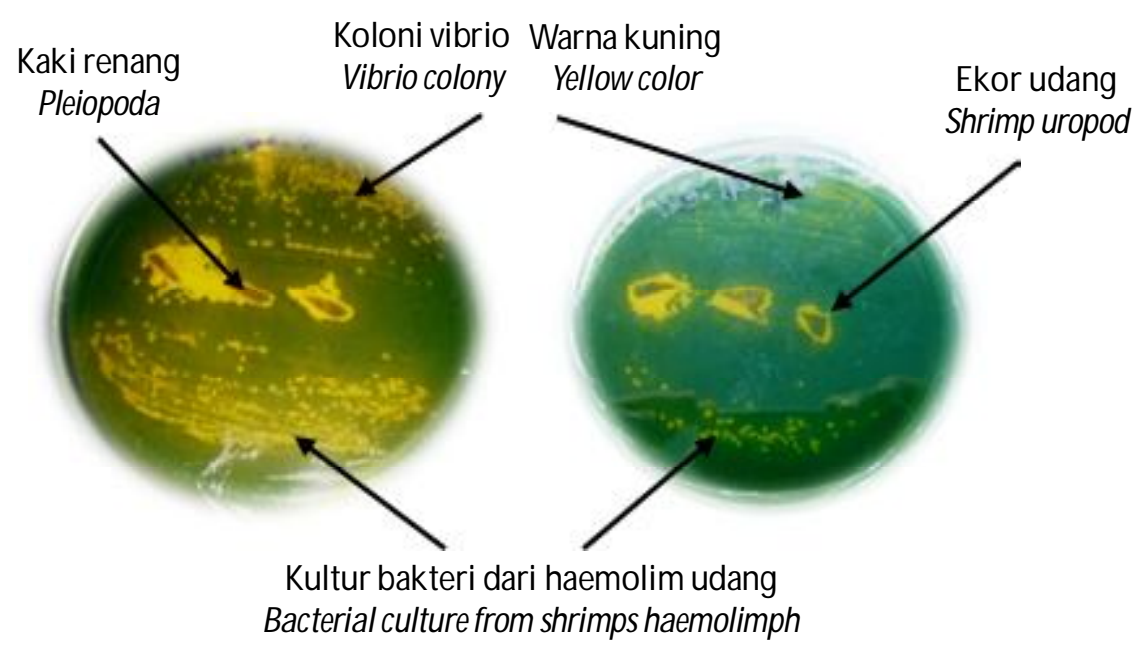

Gambar 1. Koloni bakteri yang tumbuh pada media TCBSA dari organ (kaki renang dan ekor) dan haemolim udang sakit hasil infeksi buatan

Figure 1. Colony of bacteria growing on TCBSA media from organs (pleiopoda and tail) and haemolimph of artifically infected shrimps 
protease, phospholipase, dan haemolisin. Aktivitas enzim-enzim ini pada Vibrio yang ditemukan pada udang penaeid lebih virulen dibandingkan pada spesies lainnya (Liu et al., 1996). Adanya metode deteksi dini yang dapat dengan cepat mendeteksi adanya kontaminasi bakteri patogen Vibrio berpendar akan sangat membantu dalam penanganan dan pencegahan awal untuk mengurangi kematian udang. Mengingat kemampuan bakteri dalam menginfeksi inangnya dipengaruhi oleh kepadatan bakteri dalam media budidaya, maka deteksi keberadaan bakteri sebelum jumlahnya mencapai quorum dapat dilakukan secara lebih cepat sebagai upaya pencegahan penyakit vibriosis.

\section{Hasil Deteksi Vibriosis untuk Sampel dari Tambak Udang}

Hasil deteksi vibriosis secara molekuler pada sampel yang dikumpulkan dari berbagai daerah dapat dilihat pada Gambar 3-6. Dari hasil yang diperoleh dapat diketahui bahwa kemampuan primer IAVh untuk deteksi vibriosis pada udang yang diperoleh dari tambak cukup baik. Pada hampir semua sampel, keberadaan bakteri Vibrio patogen dapat dideteksi walaupun pada konsentrasi yang rendah. Hal ini dapat kita lihat pada hasil PCR dari sampel Takalar (enam sampel), Pinrang, Maros (sembilan sampel), dan Lampung (enam sampel) (Gambar 3) terinfeksi Vibrio. Walaupun demikian kondisi udang dinyatakan tetap aman karena konsentrasi bakteri hanya berada pada kisaran $10^{1} \mathrm{CFU} / \mathrm{mL}$. Hal ini dapat dilihat dari ketebalan pita DNA hasil elektroforesis (Kadriah, 2012). Tidak terdapat pita DNA pada hasil PCR untuk sampel yang berasal dari Karawang, Situbondo, Pangkep, dan Bulukumba (Gambar 4-6). Hasil analisis PCR menunjukkan sampel yang terdeteksi positif terinfeksi Vibrio patogen adalah sampel yang berasal dari Kabupaten Pinrang, Takalar, Maros, dan Lampung.

Hasil ini menggambarkan kondisi udang yang dibudidayakan di daerah-daerah tersebut cukup aman dari serangan Vibrio patogen. Hasil PCR positif ditemukan pada sampel dari Kabupaten Pinrang (Gambar 6). Terdapat pita DNA pada hasil visualisasi dengan elektroforesis pada panjang basa $151 \mathrm{bp}$.

Tabel 1. Hasil uji biokimia lima koloni bakteri Vibrio terpilih

Table 1. Result of biochemical test of five Vibrio colony selected

\begin{tabular}{|c|c|c|c|c|c|}
\hline \multirow{2}{*}{$\begin{array}{l}\text { Uji biokimia } \\
\text { Biochemical test }\end{array}$} & \multicolumn{5}{|c|}{ Kode isolat (Isolates code) } \\
\hline & 1 & 2 & 3 & 4 & 5 \\
\hline Swarming & - & - & - & - & - \\
\hline Luminescence & + & + & + & + & + \\
\hline VP Test & - & - & - & - & - \\
\hline Arginine dihydr & + & - & - & - & - \\
\hline Gas form glucose & - & - & - & - & - \\
\hline Growth at $40^{\circ} \mathrm{C}$ & + & + & + & + & + \\
\hline Lysine decarb & + & + & + & + & + \\
\hline Pigmentation & - & - & - & + & - \\
\hline Amylase & + & + & + & + & + \\
\hline Sucrose & - & - & - & - & - \\
\hline Indole & - & - & - & - & - \\
\hline Ornithine decarb & - & + & + & + & - \\
\hline Putrescine & + & - & - & - & - \\
\hline Ethanol & - & - & - & - & - \\
\hline Serine & - & + & + & + & - \\
\hline Heptanoate & - & - & - & + & - \\
\hline Xanthine & - & - & - & - & - \\
\hline Aminobutyrate & + & - & - & - & - \\
\hline Arabinose & - & - & - & - & - \\
\hline Cellubiose & - & + & + & + & - \\
\hline Glucoronate & - & + & + & + & + \\
\hline Ketoglutarate & - & - & - & - & - \\
\hline L-alanine & + & + & + & + & - \\
\hline Leucine & - & + & + & - & + \\
\hline Propionate & + & + & - & + & - \\
\hline Species & V. campbellii & V. mimicus & V. mimi/harveyi & V. harveyi & V. mimicus \\
\hline
\end{tabular}




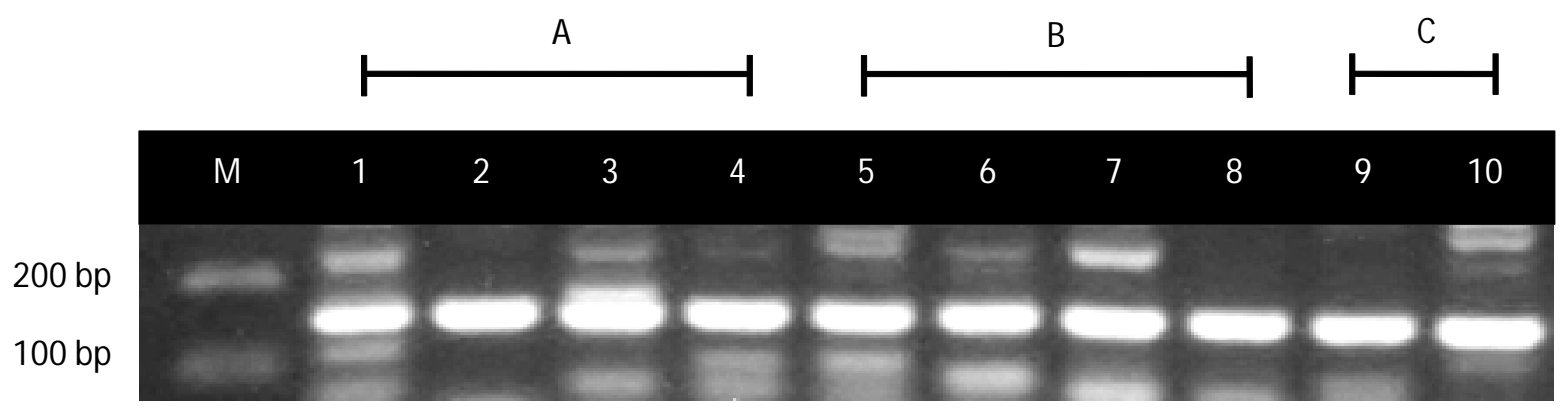

Gambar 2. Hasil amplifikasi PCR dari organ udang windu sakit dari infeksi buatan menggunakan primer IAVh; A) konsentrasi bakteri $10^{4} \mathrm{CFU} / \mathrm{mL}$ dengan template DNA dari jaringan kaki jalan, ekor, insang, kaki renang; B) konsentrasi bakteri $10^{4} \mathrm{CFU} / \mathrm{mL}$; C) konsentrasi $10^{6} \mathrm{CFU} / \mathrm{mL}$; $\mathrm{M}=$ marker 100 bp DNA ladder

Figure 2. The PCR amplification result of black tiger shrimp organ collected from articial infection using primary IAVh; A) bacteria concentration of $10^{2} \mathrm{CFU} / \mathrm{mL}$ with DNA template from periopod, telson, gill, pleopod; B) bacteria concentration of $10^{4} \mathrm{CFU} / \mathrm{mL}$; C) bacteria concentration of $10^{6} \mathrm{CFU} / \mathrm{mL}$ ); $M=$ is 100 bp DNA ladder marker

$300 \mathrm{bp}$

$200 \mathrm{bp}$

$100 \mathrm{bp}$

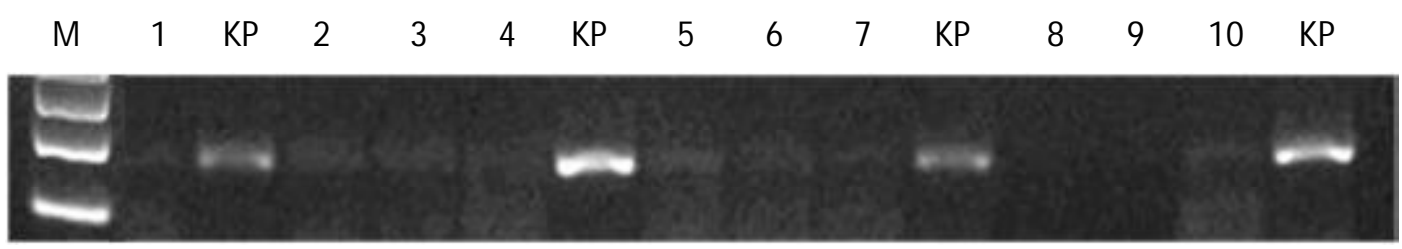

\section{$\begin{array}{llllllllllllllll}\text { M } & 11 & 12 & 13 & 14 & \text { KP } & 15 & 16 & 17 & \text { KP } & 18 & 19 & 20 & \text { KP } & 21 & 22\end{array}$}

$300 \mathrm{bp}$

$200 \mathrm{bp}$

$100 \mathrm{bp}$

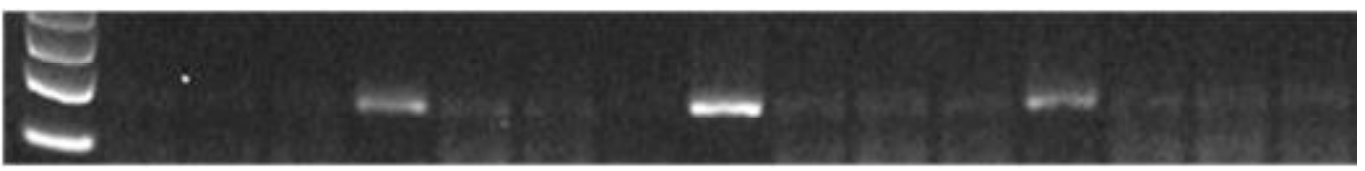

Gambar 3. Hasil deteksi vibriosis menggunakan PCR untuk sampel udang dari tambak; lajur 1-6= sampel udang vaname dari Takalar; lajur 7-16= sampel udang windu dari Maros; lajur $17-22=$ sampel $u$ dang vaname dari Lampung; $\mathrm{KP}=$ kontrol positif; $\mathrm{M}=$ marker 100 bp DNA ladder

Figure 3. PCR results for vibriosis detection from shrimp; line 1-6= DNA template from Pacific white shrimp Takalar; line 7-16= DNA template from black tiger shrimp Maros; and line 17-22= DNA template from Pacific white shrimp Lampung; $K P=$ positive control, $M=100$ bp DNA ladder marker

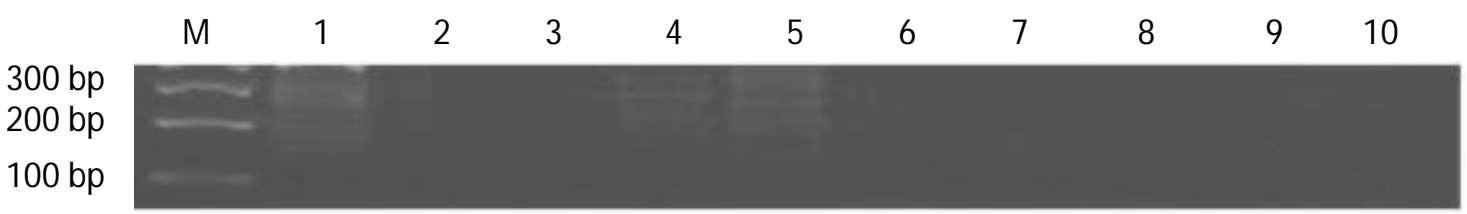

Gambar 4. Hasil PCR untuk deteksi vibriosis; lajur 1-6= template dari sampel udang Situbondo (Paras Duwet): tutup insang, insang, hepatopankreas, kaki jalan, kaki renang, ekor; lajur 7-10= template dari sampel udang Pangkep: hepato pankreas, kaki jalan, kaki renang, ekor

Figure 4. PCR results for vibriosis detection; line 1-6= template from shrimp farms in Situbondo (Paras Duwet): operculum, gill, hepatopancreas, periopoda, pleiopoda, and telson; line 7-10= template from shrimp Pangkep: hepatopancreas, periopoda, pleiopoda, and telson 


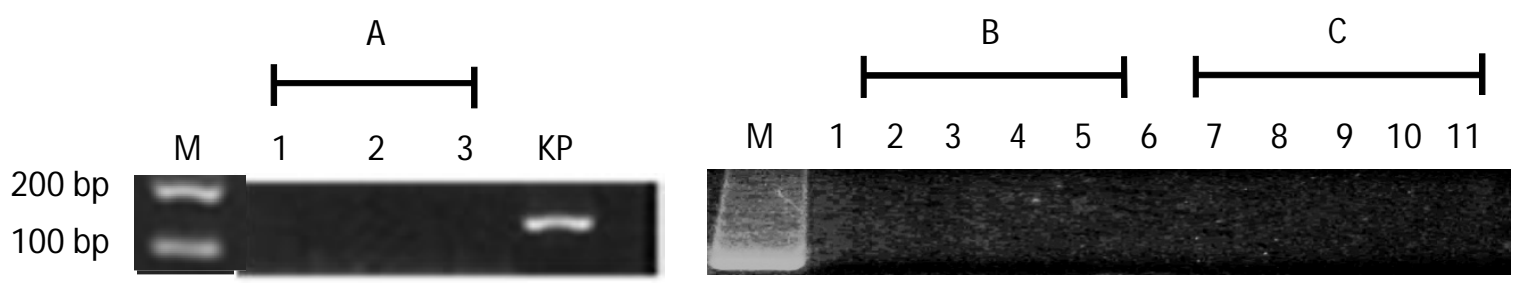

Gambar 5. Hasil uji deteksi vibriosis dengan PCR pada udang di tambak dari beberapa daerah; A) Desa Panarukan Situbondo, B) udang windu dari Bulukumba, C) udang windu dari Karawang

Figure 5. PCR results for shrimp colected for various farms from different areas; A) sample collected from Village of Panarukan Situbondo, B) tiger shrimp sample collected from Bulukumba, C) tiger shrimp sample collected from Karawang

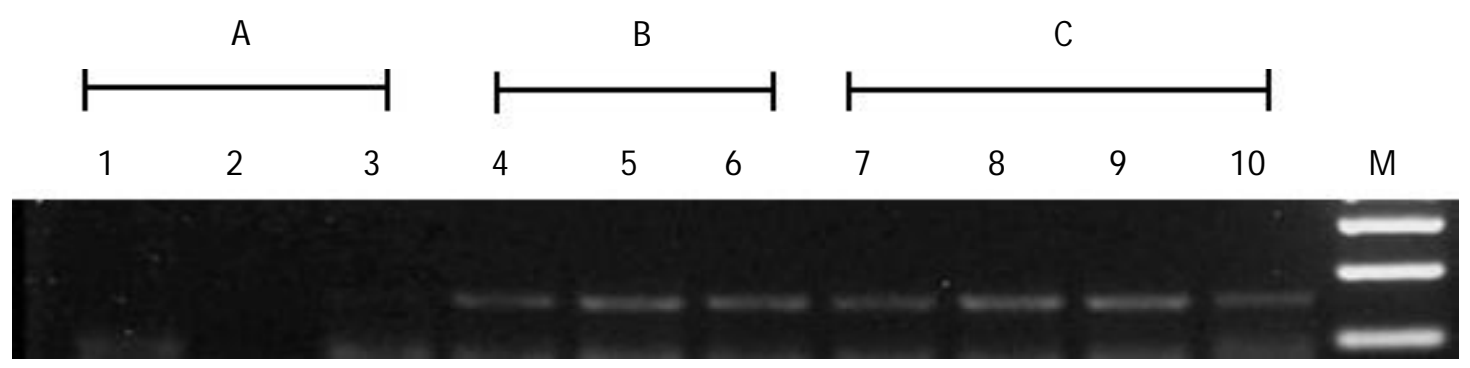

Gambar 6. Hasil PCR sampel udang Windu dari Kabupaten Barru (A), udang windu dari Kabupaten Pinrang (B), udang vaname dari Kabupaten Pinrang (C)

Figure 6. $\quad$ PCR results for tiger shrimp samples collected from Barru (A), tiger shrimps samples from Pinrang (B), Vannamei shrimps samples from Pinrang (C)

Tabel 2. Hasil deteksi vibriosis menggunakan penanda molekuler spesifik IAVh Table 2. Vibriosis detection results using molecular markers specific of IAVh

\begin{tabular}{lccc}
\hline $\begin{array}{c}\text { Lokasi } \\
\text { Location }\end{array}$ & $\begin{array}{c}\text { Jumlah sampel } \\
\text { Number of Sample }\end{array}$ & $\begin{array}{c}\text { Sampel positif } \\
\text { Sample infected (positive) }\end{array}$ & $\begin{array}{c}\text { Persentase } \\
\text { Percentage (\%) }\end{array}$ \\
\hline Takalar & 6 & 6 & 100 \\
Maros & 10 & 4 & 40 \\
Barru & 3 & 0 & 0 \\
Pinrang & 7 & 7 & 100 \\
Pangkep & 4 & 0 & 0 \\
Bulukumba & 4 & 0 & 0 \\
Lampung & 6 & 6 & 100 \\
Karawang (Sungai Buntu + BLUPPB) & 4 & 0 & 0 \\
Situbondo & 9 & 0 & 0 \\
\hline
\end{tabular}

Berdasarkan hasil uji biokimia diketahui bahwa keberadaan bakteri Vibrio berpendar patogenik tidak berhasil dideteksi secara spesifik. Walaupun terdapat koloni yang teridentifikasi sebagai V. harveyi namun tidak ada koloni bakteri berpendar yang ditemukan. Hasil ini tidak cocok dengan bakteri yang diinfeksikan.

Bakteri yang diinfeksikan adalah koloni Vibrio berpendar sehingga seharusnya terdapat koloni Vibrio berpendar pada hasil isolasi kembali bakteri dari organ udang sakit. Meto de konvensional menggunakan media agar selektif (TCBSA) terbukti tidak dapat mendeteksi keberadaan Vibrio berpendar patogenik dari jaringan udang dan media pemeliharaan. Diduga pertumbuhan bakteri Vibrio berpendar patogenik pada media TCBSA tidak mampu bersaing dengan bakteri Vibrio non-patogenik yang secara alami hidup pada media pemeliharaan dan di dalam organ udang. Biasanya koloni bakteri berpendar yang dapat diamati di media TCBSA kepadatannya lebih dari $10^{4} \mathrm{CFU} / \mathrm{mL}$. 
Proses diagnosa secara biokimia, membutuhkan waktu sekitar 3-7 hari dengan populasi bakteri yang dapat dihitung lebih dari $10^{4} \mathrm{CFU} / \mathrm{mL}$. Pada kondisi seperti ini sudah terlambat untuk melakukan usaha pencegahan penyakit, karena populasi bakteri sudah terlalu melimpah. Hal inilah yang menjadi alasan sulitnya untuk melakukan upaya pencegahan penyakit jika berdasarkan munculnya gejala klinis di tambak budidaya udang, karena kepadatan bakteri sudah tinggi.

\section{KESIMPULAN}

Penanda molekuler spesifik hemolysin IAVh terbukti mampu mendeteksi keberadaan bakteri Vibrio berpendar patogenik dari organ udang secara lebih sensitif dan spesifik, baik pada sampel hasil infeksi buatan maupun pada sampel dari tambak udang. Hasil analisis PCR menunjukkan sampel yang terdeteksi positif terinfeksi Vibrio patogen adalah sampel yang berasal dari Kabupaten Pinrang, Takalar, Maros, dan Lampung.

\section{UCAPAN TERIMA KASIH}

Penelitian ini dibiayai oleh DIPA BPPBAP Maros tahun 2015. Terima kasih kami sampaikan kepada peneliti dan teknisi Kelompok Kesehatan Ikan dan Lingkungan, Balai Penelitian dan Pengembangan Budidaya Air Payau, Maros yang telah berpartisipasi, berperan aktif, dan membantu selama penelitian ini berlangsung.

\section{DAFTAR ACUAN}

Alsina, M., \& Blanch, AR. (1994). A set of keys for biochemical identification of environmental Vibrio species. J. Appl. Bacteriol., 76, 79-85.

Austin, B. (1991). Methods in aquatic bacteriology. John Willey and Sons. Chichester. New York. Brisbane. Toronto. Singapore, 425 pp.

Austin, B., \& Austin, D.A. (1993). Bacterial fish pathogens. Disease in Farmed and Wild Fish. Second Edition. New York. London.

Austin, B., \& Zhang, X.H. (2006). Vibrio harveyi: a significant pathogen of marine vertebrates and invertebrates. Lett. Appl. Microbiol., 43, 119-124.

Baumann, P., Furniss, A.L., \& Lee, J.V. (1994). Facultative anaerobic gram negative rods. In Holt, J.G., Krieg, N.R., Sneath, P.H.A., Staley, J.T., \& Wilins, S.T. (Eds.). Bergey's manual of determinative bacteriology. The William and Wilkins. Ninth Edition. Baltimore.
Brock, T.D., Madigan, M.T., Martinko, J.M., \& Parker, J. (1994). Biology of Microorganism. Seventh Edition. Prentice Hall International, Inc.

Conejero, M.J.U., \& Hedreyda, C.T. (2004). PCR detection of hemolysin (vhh) gene in Vibrio harveyi. J. Gen. Appl. Microbiol., 50, 137-142.

Cunningham, C.O. (2002). Molecular diagnosis of fish and shellfish diseases: present status and potential use in disease control. Aquaculture, 206, 1955.

Christopher, M., Caipang, A., \& Aguana Mary, P.N. (2011). Conventional PCR assays for the detection of pathogenic Vibrio spp. in shrimp aquaculture in the Philippines. International Journal of the Bioflux Society, 4(3).

Dorsch, M., Lane, D., \& Stackebrandt, E. (1992). Towards a phylogeny of the genus Vibrio based on 165 rRNA sequences. Int. J. Syst. Bacteriol., 42, 5863.

Hai, N.V. (2015). The use of probiotics in aquaculture. Journal Applied Microbiology, 119, 917-935.

Kadriah, I.A.K. (2012). Pengembangan metode deteksi cepat Vibrio berpendar patogenik pada udang penaeid. Disertasi. Institut Pertanian Bogor.

Kadriah, I.A.K., Susianingsih, E., Sukenda., Yuhana, M., \& Harris, E. (2013a). Desain primer spesifik untuk deteksi dini penyakit vibriosis pada udang penaeid. J. Ris. Akuakultur, 8(1), 131-143.

Kadriah, I.A.K., Sukenda, Yuhana, M., Susianingsih, E., \& Atmomarsono, M. (2013b). Specificity of Haemolysin and Gyrase gene marker for rapid detection of vibriosis on penaeid shrimp. Indonesian Aquaculture Journal, 8(1), 47-64.

Karunasagar, I., Pai, R., Malathi, G.R., \& Karunasagar, I. (1994). Mass mortality of Penaeus monodon larvae due to antibiotic-resistant Vibrio harveyi infection. Aquaculture, 128, 203-209.

Leano, E.M., Lavilla-Pitogo, C.R., \& Paner, M.G. (1998). Bacterial flora in the hepatopancreas of pondreared Penaeus monodon juveniles with luminous Vibriosis. Aquaculture, 164, 367-374.

Liu, P.C., Lee, K.K., \& Chen, S.N. (1996). Pathogenicity of different isolates of Vibrio harveyi in tiger prawn, Penaeus monodon. Lett. Appl. M icrobiol., 22, 413-416.

Mamiatis, T., Fritsch, E.F., Sambrook, J., \& Engel, J. (1982). Molecular cloning; A laboratory manaual. Cold Sping Harbor. New York, 545 pp.

Muir, P. (1996a). Media used in Vibrio and photobacterium identification. Department of Mi- 
crobiology, Biomedical and Tropical Veterinary Sciences. James Cook University of North Queensland. Australia.

Muir, P. (1996b). Identification of Vibrio and Pseudomonas bacteria. Department of Microbiology, Bio- medical and Tropical Veterinary Sciences. James Cook University of North Queensland. Australia. Pang, L., Zhang, X.H., Zhong. Y., Chen, J., Li, Y., \& Austin, B. (2006). Identification of Vibrio harveyi using PCR amplification of the toxR gene. Lett. Appl. Microbiol., 43, 249-255. 